\title{
CHARACTERIZATION OF THE AGRICULTURE OCCUPATION IN THE CERRADO BIOME USING MODIS TIME-SERIES
}

\author{
Antonio Felipe Couto Junior ${ }^{1}$, Osmar Abílio de Carvalho Júnior², \\ Éder de Souza Martins ${ }^{3}$ and Vinícius Vasconcelos ${ }^{3}$
}

\begin{abstract}
This paper aims to characterize the agriculture expansion in the Cerrado biome using time-series data of Moderate Resolution Imaging Spectroradiometer (MODIS) sensor. The study area is the municipality of Luís Eduardo Magalhães (Bahia State, Brazil), with recent growth of agribusiness. The methodology can be subdivided into the following steps: 1) noise reduction, 2) endmembers identification, and 3) mixing linear analysis. In the noise reduction was applied the following procedures: 1) moving median filter; 2) Minimum Noise Fraction (MNF) transformation, and 3) Inverse MNF transformation. The results provided a significant noise reduction, besides eliminating the atmospheric interferences. Three endmembers were identified: 1) Natural Vegetation; 2) Agriculture; 3) Change Areas (conversion). We used the linear mixture analysis with the selected endmembers to generate fraction images. These images evidenced the agriculture expansion from west to east. These methods overcame the spatial resolution restrictions and evidenced the potential for discriminating the phenology of growing agricultural crops.
\end{abstract}

Keywords: agriculture expansion, cerrado, time-series, MODIS, change detection.

RESUMO. 0 artigo objetiva caracterizar a expansão agrícola no bioma Cerrado utilizando dados de séries temporais do sensor Moderate Resolution Imaging Spectroradiometer (MODIS). A área de estudo é o município de Luís Eduardo Magalhães (Bahia), com recente crescimento do agronegócio. A metodologia pode ser subdividida nas seguintes etapas: (a) redução do ruído, (b) identificação dos membros finais, e (c) análise linear de mistura. Na redução do ruído foram aplicados os seguintes procedimentos: (a) filtro de mediana, (b) transformação Minimum Noise Fraction (MNF), e (c) transformação inversa MNF. Os resultados proporcionaram uma redução significativa dos ruídos, além da eliminação de interferências atmosféricas. Três membros finais foram identificados: 1) Vegetação Natural; 2) Agricultura; 3) Área de Mudança (Conversão). Foi usada a análise de mistura linear com os membros finais selecionados para gerar as imagens de fração. Estas imagens evidenciaram a expansão agrícola partindo de oeste para leste. Os métodos apresentados proporcionaram a superação da limitação da resolução espacial e evidenciaram um potencial de discriminação da fenologia de cultivos agrícolas.

Palavras-chave: expansão agrícola, cerrado, séries temporais, MODIS, detecção de mudança.

\footnotetext{
1 Universidade de Brasilia, Campus Planaltina, 70910-900 Planaltina, DF, Brazil. Phone: +55(61) 3107-8002 - E-mail: afcj@unb.br

2Universidade de Brasília, Departamento de Geografia, Campus Universitário Darcy Ribeiro, Asa Norte, 70910-900 Brasília, DF, Brazil. Phone: +55(61) 3307-1559; Fax: +55(61) 3272-1909 - E-mail: 0smarjß@unb.br

3 Embrapa - Centro de Pesquisa Agropecuária dos Cerrados, 73301-970 Planaltina, DF, Brazil. Phone: +55(61) 3388-9803 / 3388-9862

- E-mails: eder@cpac.embrapa.br; vinicius.vasconcelos@soilenvironment.com
} 


\section{INTRODUCTION}

The modern society depends on natural resources and crop areas for food production (Ramankutty \& Foley, 1998). Approximately half of the terrestrial ecosystems without ice cover have already been converted or significantly modified by human activities (Ramankutty \& Foley, 1998; Lambin et al., 2003). These landcover changes were intensified by the global population growth over the past 300 years (Goldewijk \& Ramankutty, 2004), affecting the biogeochemical cycles (Ramankutty \& Foley, 1998), biodiversity (Lambin et al., 2003) and soil conservation (Trimble \& Crosson, 2000).

Land-cover monitoring has been developed to understand the biologic system capacity to support human needs (Vitousek et al., 1997). Thus, the development of orbital sensors with high temporal-resolution (such as Moderate Resolution Imaging Spectroradiometer - MODIS sensor) allows a continuous monitoring of the earth's surface. (Huete et al., 2002; Latorre et al., 2007; Carvalho Júnior et al., 2008, 2009). These sensors obtain accurate measurements of the land-cover dynamics at regional to global scale, favoring the phenological studies of crops and natural areas (Kang et al., 2003; Zhang et al., 2003; Sakamoto et al., 2005). In this approach, vegetation indices are most widely used for temporal analysis and change detection (Huete, 1988; Prince, 1991 a,b; Tucker et al., 1991; Defries \& Townshend, 1994; Running et al., 1995; Wessels et al., 2004).

Thus, the digital image processing considering temporal patterns leads to a conceptual change in the remote sensing techniques. This paper aims to characterize the agriculture occupation in the Cerrado biome using MODIS time-series vegetation index data.

\section{STUDY AREA}

The study area is the Luís Eduardo Magalhães (LEM) municipality, mesoregion of Western Bahia State, entirely inside the Cerrado Biome (Fig. 1). Its area is around $4,000 \mathrm{~km}^{2}$ and its population is nearly 60,000 habitants (IBGE, 2010).

The climate of the study area is divided in two well-defined seasons: a dry and cold season (from May to September) and a rainy and hot season (from October to April). The annual average precipitation is around $1,500 \mathrm{~mm}$, varing from east to west. Annual average maximum and minimum temperature varies between $21^{\circ}$ and $27^{\circ} \mathrm{C}$, respectively (Batistella et al., 2002).

In the geologic context, the area is over Late Cretaceous sediments of the Urucuia Group, constituted almost exclusively by eolian sandstone (Campos \& Dardenne, 1997). Alluvial deposits present in the large rivers are composed by sand and gravel (Silva, 2008).

LEM has a flat topography and average altitude of 900 meters (Castro et al., 2010). The soils are predominantly deep, well-weathered, nutrient-poor and acid, standing out Latosoil and Neosoil (Batistella et al., 2002). The altitude and the soil are the main determinant attributes of the floristic composition and vegetation structure in Cerrado physiognomies (Felfili \& Silva Júnior, 2001). Agriculture and livestock activities occupied around $50 \%$, in which the main products are: soya, corn, cotton and coffee (Batistella et al., 2002; Menke et al., 2009).

\section{MATERIAL AND METHODS}

\section{MODIS sensor data}

The MODIS data aim to support the earth's surface change assessment, providing a broader understanding of the global system functioning (Justice et al., 2002). These high temporal-resolution data are freely available at National Aeronautics Space Adiministration (NASA), being georeferenced and corrected for the atmospheric effects, like clouds and aerosols, among others (Wolfe et al., 1998; Justice et al., 2002).

In this work was used the Normalized Difference Vegetation Index (NDVI), from the MOD13 product (16-days composite and 250 meters). This product is generated from the daily surface reflectance (MOD09 - level 2) and is corrected for molecular scattering, ozone and aerosol absorption (Vermote et al., 2002). The vegetation index algorithm uses the surface reflectance data at level $2 \mathrm{G}$ (reprojected) and makes a 16 day temporal composition of these data (level 3).

The temporal series was generated with these co-registered data, producing a temporal cube, where $X$ refers to longitude; $Y$, to latitude; and $Z$, to the Vegetation Index values (Fig. 2). In this context, the $Z$ profile represents the target behavior along the time, and it is called temporal signature, similarly to the spectral signature related to hyperspectral data.

\section{Noise treatment}

The temporal series has limitations caused by atmospheric interferences, cloud covers, radiometric variation (sensor oscillation, solar illumination, among others) or reveals the presence of other noises which are common features in the remote sensing (Du et al., 2001; Furby \& Campbell, 2001). In this study, noise reduction was achieved using the following methods (Carvalho Júnior et al., 2008, 2009): (a) moving filter; (b) Minimum Noise Fraction (MNF) transformation; and (c) Inverse MNF transformation. 

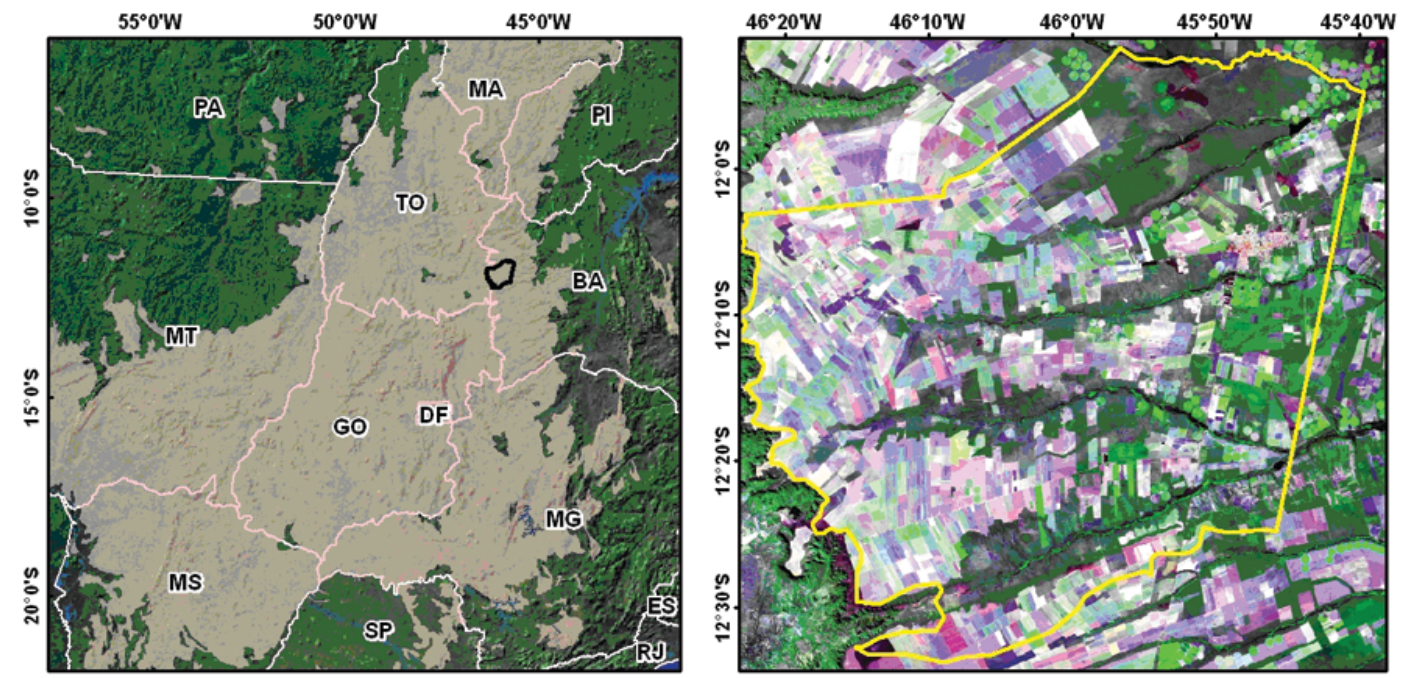

Figure 1 - The Cerrado Biome and the study areas (in black) [left side image]; Luís Eduardo Magalhães limit [right side image].

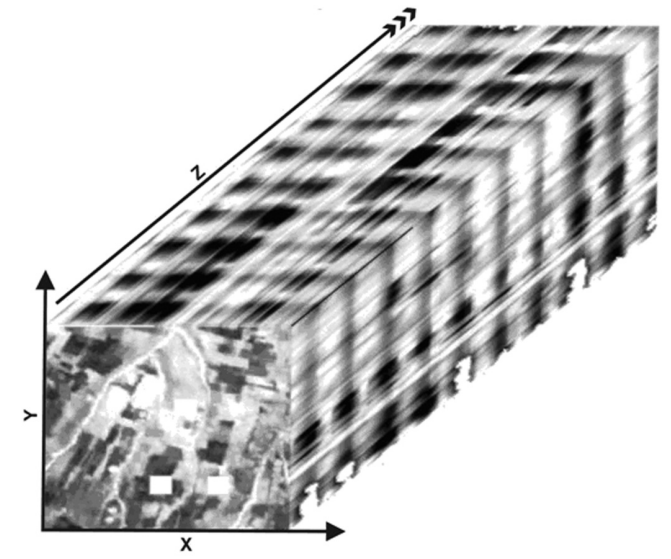

Figure 2 - 3D-temporal cube generated from co-registered images in an increasing sequence corresponding to 10 years.

The median filter is a particular case of the $i^{\text {th }}$ order statistic of a real number series, using a moving window over the temporal signature and generating median values. Organizing the observations in an increasing order, the median generates the central value of the window, requiring simple nonlinear operation.

The Minimum Noise Fraction (MNF) was originally developed to the hyperspectral image processing (Green et al., 1988) and it is also adequate for noise reduction of aerial gamma-ray survey (Dickson \& Taylor, 1998). MNF is a linear transformation similar to the Principal Component Analysis (PCA), which maximizes the signal/noise ratio to order the images according to their quality (Green et al., 1988).

The separation of signal and noise components was obtained from visual inspection of the image quality and eigenvalue plot analysis. Considering only the signal components, the inverse
MNF transformation is performed in order to reset the values related to the time-series vegetation indices, in which the white noise is eliminated (non-correlated noises with low variance).

In the noise reduction, the use of MNF alone (Carvalho Júnior et al., 2006; Couto Júnior et al., 2011) or combined with the median filter (Carvalho Júnior et al., 2008, 2009, 2012; Santana et al., 2010) has produced positive results to identify and characterize the Cerrado physiognomies.

\section{Endmember Detection and Linear Mixture Analysis of Temporal Series}

The convex geometry (simplex model) is intensely used to detect endmembers, as it establishes a spatial arrangement for image pixels that describes the material mixture relations (Tompkins et al., 1997; Winter, 1999; Batenson et al., 2000; Berman et al., 2004; Carvalho Júnior et al., 2005). This geometry is visualized in a $\mathrm{n}$-dimensional space, where the axes are non-correlated and describe the inherent dimensionality, such as the Principal Component Analysis - PCA and MNF components (Smith et al., 1985, 1990; Bateson \& Curtiss, 1993, 1996; Boardman, 1993). The vertices of this simplex are the pure pixe/s, while the other pixe/s inside the convex polygon are the results of their mixtures (Carvalho Júnior et al. 2003).

Carvalho Júnior et al. (2008) used this analysis with temporal series considering natural area. In this work, this procedure is used in natural and in agricultural areas. This approach allows a new conception for the convex geometry, in which we can notice vertices that represent time-invariant elements (same annual cycle) and other vertices that present strong changes of the land-use. 


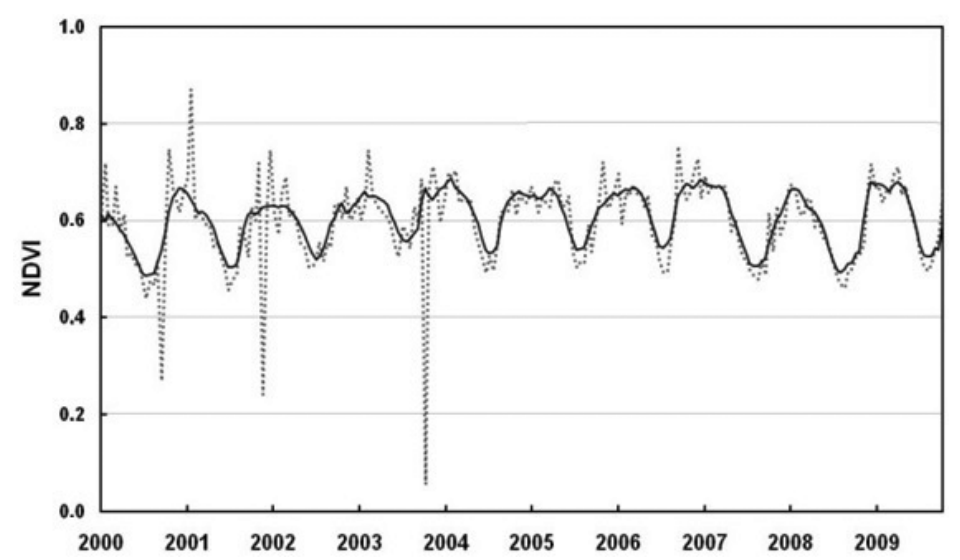

Figure 3 - Original NDVI temporal profiles (dotted line) with noises. Temporal profiles smoothed through median filter and Minimum Noise Fraction (MNF) association (black line).

The presence of two invariant points related to agriculture and natural areas establishes an invariant axis, while the opposite vertex represents areas that present changes related to the conversion, i.e. that vary in the annual cycle.

The linear mixture analysis was applied to the temporal series (Adams et al., 1995). Differently from the traditional spectral mixture analysis, in this approach we used temporal profiles with constant and variable annual cycles. This procedure allows us to describe the intensity of change, which opposes the initial proposal of quantifying the percentage of pure elements inside the pixel.

\section{RESULTS}

\section{Noise treatment results}

The combination of median filter and MNF transformation is very simple and fast. This combination also improved the data quality; reducing significantly impulse-type noises and eliminating areas with cloud cover or shade (Fig. 3).

This work used a median filter with window size equal to seven, eliminating impulse-type noises. Despite this elimination procedure, some degrees may be generated due to the value repetition.

MNF transformation ordered the data according to the signal/noise ratio, where the signal fractions are in the first components. In this study, the 20 first components were considered as signal fraction, according to the eigenvalue plot and image visual quality (Fig. 4). MNF inverse transformation generated a smoothed curve without white noises (non-correlated and low variance) and eventual small degrees (repeated value succession) produced after the median filtering (Fig. 3).

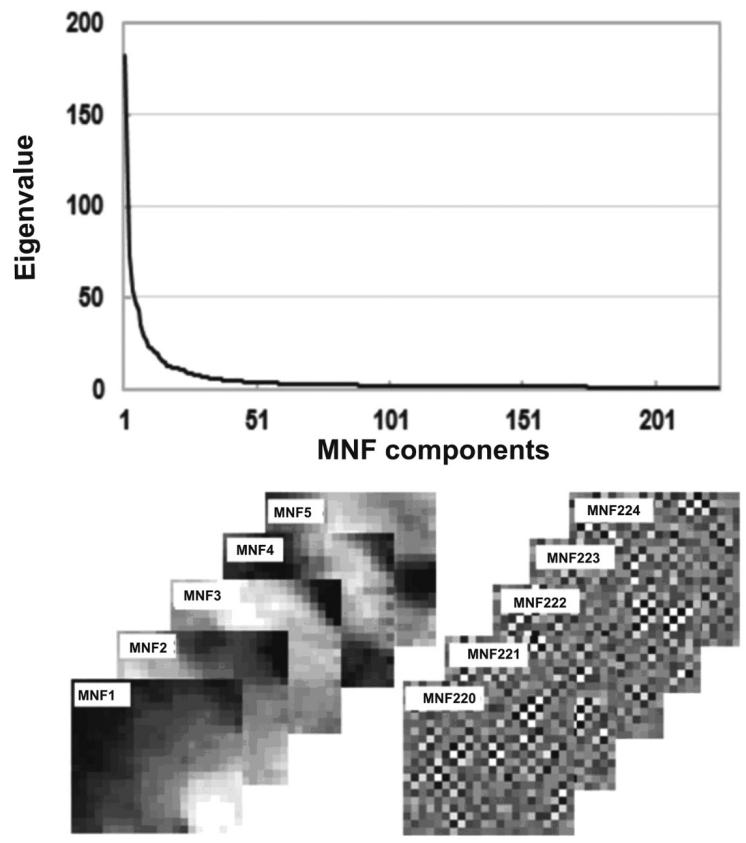

Figure 4 - Eigenvalue plot (superior) and image decreasing quality (inferior).

\section{Endmember results and Multiple Linear Regression of the Temporal Profiles}

The scatter plot of the two first MNF components evidenced a triangular distribution of the data (Fig. 5). This triangle is rotated in order to place the invariant axis at its base, containing in its extremes the endmembers related to Natural Vegetation (1) and Agriculture (2). The third vertex corresponds to Change Area, i.e. area converted from natural to agricultural patterns. Thus, the distance from the Cerrado-Agriculture invariant axis represents areas with larger inter-annual changes (Fig. 5). 


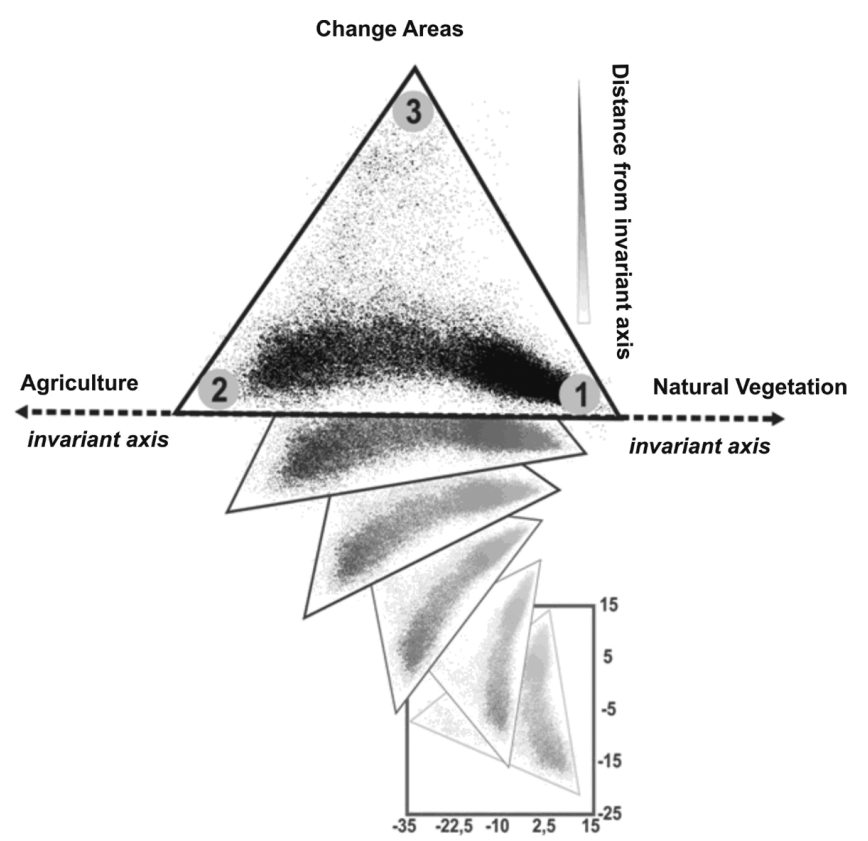

Figure $\mathbf{5}$ - Scatter plot between $1^{\text {st }}$ and $2^{\text {nd }}$ MNF component; the numbers correspond to endmembers.

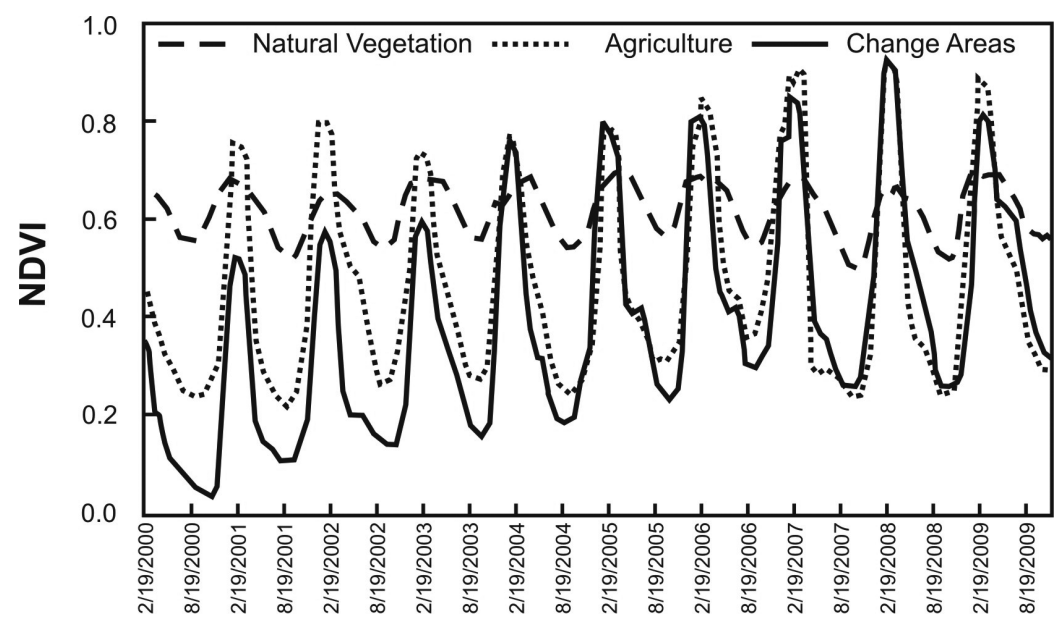

Figure 6 - Average temporal signatures of the endmembers.

The Cerrado endmember contains the phytophysiognomy in its natural state, presenting floristic wealth similar to other areas inside the biome (Felifili \& Silva Júnior, 2001) (Fig. 5). The temporal profiles of preserved natural vegetation showed an average NDVI value of 0.6 with variations between 0.5 and 0.7 correspond to phenological behavior during the seasons, dry and rainy, respectively (Fig. 6).

The agriculture is represented by managements employed for more than 10 years. This cover presents a seasonal variation over $60 \%$ (Fig. 6), according to the management step (for example, planting, canopy closure and harvesting). The greatest NDVI values ( 0.8) evidence the maximum vigor of the crops and, on the other hand, the minimum ones $(\sim 0.25)$ correspond to the low vegetal cover. The minor photosynthetic activity variations were observed in the areas that used the direct drilling system.

In this context, areas converted from natural vegetation to agriculture represent a fit to one of two patterns (Fig. 6). The most significant changes began in 2004. Before this period, there was a gradual increase of the NDVI values, representing the land-cover change transition. 
Linear mixture analysis was applied considering the temporal endmembers. The fraction images of Cerrado and Agriculture indicated an farming increase from west to east, confirming the scenario observed in the last decade in this municipality (Menke et al., 2009) (Fig. 7).

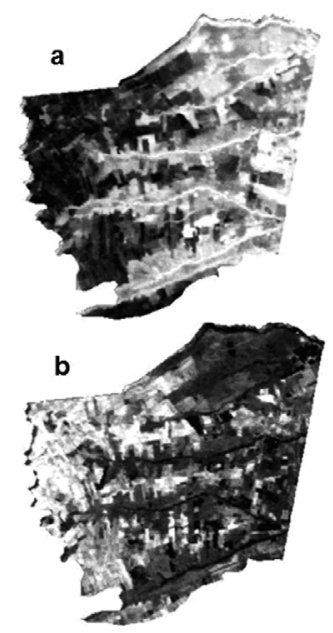

Figure 7 - Cerrado fraction image (a) and Agriculture fraction image (b)

The lighter pixels in the natural vegetation fraction image usually represent the Gallery Forest. This is due to the association to water courses, which provides conditions to keep the photosynthetic activity, even during the dry period; reducing the seasonal variations. The savannic formations showed greater seasonal variations, according the arboreous density (Fig. 8). The temporal profile of coffee crop showed a similar behavior to the natural vegetation (mainly from 2003).

Agriculture is concentrated in the western part (Fig. 7), where the flat topography and the well-distributed rainfalls occurs, provide favorable conditions for agricultural mechanization. In this region, rainfed agriculture stands out and it can be conventional (cotton) or direct drilling (soya and corn). The main difference between these two managements resides in the cover between crops, which practically does not exist in the conventional planting. This absence causes greater variation (amplitude) among the cotton management phases due to the soil exposition after harvesting (Fig. 9). In this way, the direct drilling employment, soya and corn in succession, for example, keeps the soil covered after harvesting.

The color composition (RGB) using fraction images (Agriculture, Cerrado and Change Areas) show the different spatialtemporal patterns (Fig. 10). This result converges to the work carried out by Menke et al. (2009), which used more refined spatial resolution sensors: 1) Panchromatic Remote sensing Instrument for Stereo Mapping (2.5 m); 2) LANDSAT (30 m).

\section{CONCLUSION}

The use of temporal series is an important information source for land-use monitoring in the Cerrado biome. This earth's surface monitoring has been carried out through the relation between orbital data and biophysical factors, mainly the vegetation. With the improvement of MODIS sensor, the knowledgement of land cover changes has been expanded. This sensor aims to carry out systemic and regional studies, providing a large spectrum and temporal data volume. An important characteristic of this sensor is its daily temporal resolution.

In this work, MODIS data were obtained with a 16 day interval. However, these temporal-series are influenced by noises caused by atmospheric interferences, restricting the full employment. The noise elimination method of temporal signatures combining the Median Filter and Minimum Noise Fraction (MNF) techniques (Carvalho Júnior et al., 2012) allowed generating smoothed temporal profiles, indicating the main cover and management characteristics, highlighting three endmembers, related to this dynamics.

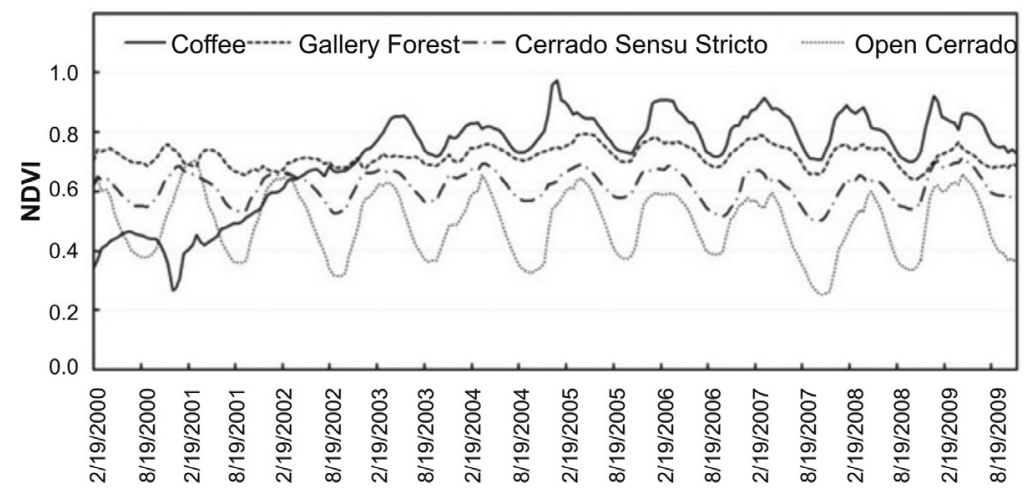

Figure 8 - Temporal profiles of the main Cerrado phytophysiognomies and coffee planting. 


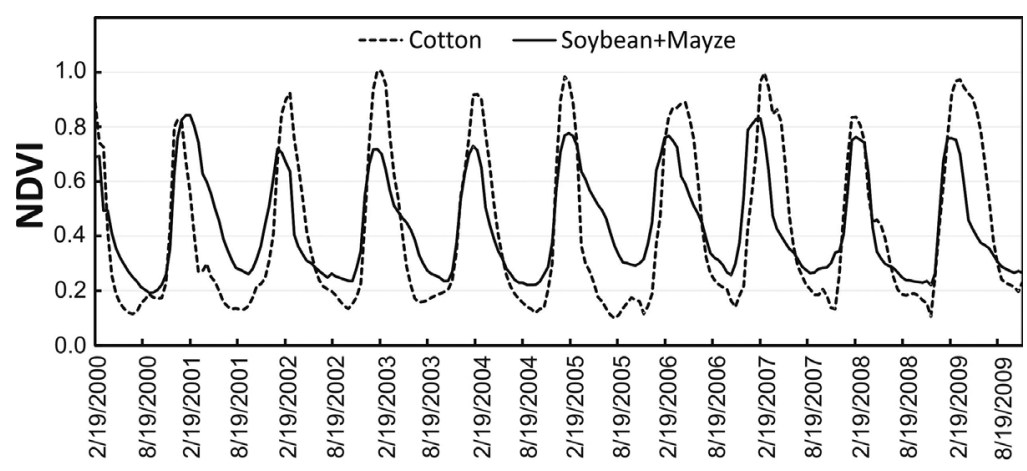

Figure 9 - Temporal profiles related to the planting of Cotton and of the Soya-Corn succession.

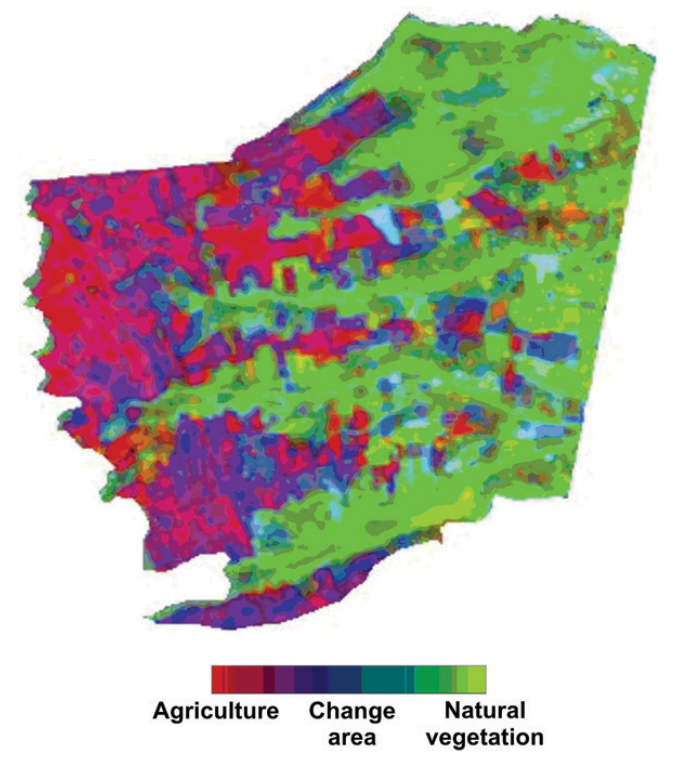

Figure 10 - Colored composition of the Temporal Linear Mixture Analysis (TLMA) fractions, in which the RGB channels correspond to Agriculture, Natural Vegetation and Change Area, respectively.

The first member is the Cerrado, that comprises the original phytophysiognomies with marked seasonality and the variation of its NDVI values associated to the photosynthetic activity and arboreous density. The second endmember corresponds to agriculture patterns, in which there is no more natural vegetation for more than one decade. Also, it is characterized by the intense NDVI amplitude, which results from the planting and havesting periods. The last endmember, called Change Area, highlights the fit to the two previous members and represents cover changes only in the last 10 years.

The methodological procedures surpassed the spatial resolution limitation through its temporal high-resolution. In this way, this work presents a potential to discriminate the landscape changes.

\section{ACKNOWLEDGMENTS}

This article has been developed in the scope of the estimated activities of the following projects: (a) "Desenvolvimento de metodologias de processamento digital de imagens de satélite multisensores para o monitoramento do uso da terra e análise ambiental dos fragmentos florestais da bacia do Rio São Francisco" which refers to the announcement 35/2006 of the CT-Hidro financed by Conselho Nacional de Desenvolvimento Científico e Tecnológico (CNPq); and (b) "Evolução e análise ambiental na região do Cerrado da Bacia do Rio São Francisco" related to the process 193.000.49/2008 financed by FAP-DF. Also, the authors would like to thank CAPES for conceding the doctorate scholarship to the researcher Antonio Felipe Couto Junior; and CNPq for financial support from fellowship the researchers: Osmar Abílio de Carvalho Júnior and Éder de Souza Martins.

\section{REFERENCES}

ADAMS JB, SABOL DE, KAPOS V, ALMEIDA FILHO R, ROBERTS DA, SMITH MO \& GILLESPIE AR. 1995. Classification of multispectral images based on fractions of endmembers: application to land-cover change in the Brazilian Amazon. Remote sensing of Environment, 52: 137-154.

BATESON CA, ASNER GP \& WESSMAN CA. 2000. Endmember bundles: a new approach to incorporating endmember variability into spectral mixture analysis. IEEE Transactions on Geoscienceand Remote Sensing, 38(2): 1083-1094.

BATESON CA \& CURTISS B. 1993. A tool for manual endmember selection and spectral unmixing. In: Annual JPL Airborne Geosciences Workshop, 4, Pasadena, CA. Summaries, JPL Publication 93-26, p. 3-6.

BATESON CA \& CURTISS B. 1996. A method for manual endmember selection and spectral unmixing. Remote Sensing of Environment, 55: 229-243. 
BATISTELLA M, GUIMARÃES M, MIRANDA EE, VIEIRA HR, VALLADARES GS \& MANGABEIRA JAC. 2002. Monitoramento da expansão agropecuária na Região Oeste da Bahia. Campinas: Embrapa Monitoramento por Satélite. Documentos, 20, 39 pp.

BERMAN M, KIIVERI H, RYAN L, ERNST A, DUNNE R \& HUNTINGTON JF. 2004. ICE: A statistical approach to identifying endmembers in hyperspectral images. IEEE Transactions on Geoscience and Remote Sensing, 42(10): 1-11.

BOARDMAN JW. 1993. Automated spectral unmixing of AVIRIS data using convex geometry concepts: In: Annual JPL Airborne Geosciences Workshop, 4, Pasadena, CA. Summaries, JPL Publication 93-26, p. 11-14.

CAMPOS JEG \& DARDENNE MA. 1997. Estratigrafia e sedimentação da Bacia Sanfranciscana: uma revisão. Revista Brasileira de Geociências, 27: 269-282.

CARVALHO JÚNIOR OA, CARVALHO APF, GUIMARÃES RF, MENESES PR \& SHIMABUKURO Y. 2003. Mistura espectral: (I) detecção dos membros finais utilizando a geometria do Simplex. Espaço Geografia, 6(1): 147-173.

CARVALHO JÚNIOR OA, GUIMARÃES RF, MARTINS ES, CARVALHO APF \& GOMES RAT. 2005. Aplicação do método de identificação espectral para imagens do sensor ASTER em ambiente de cerrado. Revista Brasileira de Geofísica, 23(2): 159-172.

CARVALHO JÚNIOR OA, HERMUCHE PM \& GUIMARÃES RF. 2006. Identificação regional da floresta estacional decidual na bacia do rio Paraná a partir da análise multitemporal de imagens MODIS. Revista Brasileira de Geofísica, 24(3): 319-332.

CARVALHO JÚNIOR OA, SAMPAIO CS, SILVA NC, COUTO JUNIOR AF, GOMES RAT, CARVALHO APF \& SHIMABUKURO YE. 2008. Classificação de padrões de savana usando assinaturas temporais NDVI do sensor MODIS no Parque Nacional da Chapada dos Veadeiros. Revista Brasileira de Geofísica, 26(4): 505-517.

CARVALHO JÚNIOR OA, COUTO JUNIOR AF, SILVA NC, MARTINS ES, CARVALHO APF \& GOMES RAT. 2009. Avaliação dos classificadores espectrais de Mínima Distância Euclidiana e Spectral Correlation Mapper em séries temporais NDVI-MODIS no campo de instrução militar de Formosa (G0). Revista Brasileira de Cartografia, 61: 399-412.

CARVALHO JÚNIOR OA, DA SILVA NC, DE CARVALHO APF, COUTO JÚNIOR AF, SILVA CR, SHIMABUKURO YE, GUIMARÃES RF \& GOMES RAT. 2012. Combining noise-adjusted principal components transform and median filter techniques for denoising modis temporal signatures. Revista Brasileira de Geofísica, 30(2): 47-157.

CASTRO KB, MARTINS ES, GOMES MP, REATTO A, LOPES CA, PASSO DP, LIMA LAS, CARDOSO WS, CARVALHO JÚNIOR OA \& GOMES RAT. 2010. Caracterização Geomorfológica do município de Luís Eduardo
Magalhães, BA escala 1:100.000. Boletim de Pesquisa e Desenvolvimento 288, Embrapa - CPAC, Planaltina, DF, 33 pp.

COUTO JÚNIOR AF, CARVALHO JÚNIOR OA, MARTINS ES, SANTANA OA, SOUZA VV \& ENCINA JI. 2011. Tratamento de ruídos e caracterização de fisionomias do Cerrado utilizando séries temporais do sensor MODIS. Revista Árvore, 35: 699-705.

DEFRIES R \& TOWNSHEND JRG. 1994. NDVI derived land cover classification at global scales. International Journal of Remote Sensing, 15: 3567-3586.

DICKSON B \& TAYLOR G. 1998. Noise reduction of aerial gamma-ray survey. Exploration Geophysics, 29: 324-329.

DU Y, CIHLAR J, BEAUBIEN J \& LATIFOVIC R. 2001. Radiometric normalization, composition, and quality control for satellite high resolution image mosaics over large areas. IEEE Transactions on Geoscience and Remote Sensing, 39: 623-634.

FELFILI JM \& SILVA JUNIOR MC. 2001. Biogeografia do bioma Cerrado: estudo fitofisionômico da Chapada do Espigão Mestre do São Francisco. Brasília, Universidade de Brasília, Departamento de Engenharia Florestal, 152 pp.

FURBY SL \& CAMPBELL NA. 2001. Calibrating images from different dates to like-value digital counts. Remote Sensing of Environment, 77 : 186-196.

GOLDEWIJK K \& RAMANKUTTY N. 2004. Land cover changes over the last three centuries due to human activities: the availability of new global data set. GeoJournal, 61: 335-344.

GREEN AA, BERMAN M, SWITZER P \& CRAIG MD. 1988. A transformation for ordering multispectral data in terms of images quality with implications for noise removal. IEEE Transactions on Geoscience and Remote Sensing, 26: 65-74.

HUETE AR. 1988. A soil-adjusted vegetation index (SAVI). Remote Sensing of Environment, 25: 295-309.

HUETE AR, DIDAN K, MIURA T, RODRIGUEZ P, GAO X \& FERREIRA LG. 2002. Overview of the radiometric and biophysical performance of the MODIS vegetation indices. Remote Sensing of Environment, 83: 195-213.

IBGE. 2010. Instituto Brasileiro de Geografia e Estatística. Censo Demográfico. Available on: www.ibge.gov.br. Access on Jan 30, 2012.

JUSTICE CO, TOWNSHEND JRG, VERMOTE EF, MASUOKA E, WOLFE RE, SALEOUS N, ROY DP \& MORISETTE JT. 2002. An overview of MODIS Land data processing and product status. Remote Sensing of Environment, 83: 3-15.

KANG S, RUNNING SW, LIM J, ZHAO M, PARK C \& LOEHMAN R. 2003. A regional phenology model for detecting onset of greenness in temperate mixed forests, Korea: An application of MODIS leaf area index. Remote Sensing of Environment, 86: 232-242. 
LAMBIN E, GEIST H \& LEPERSE. 2003. Dynamics of land-use and landcover changes in tropical regions. Annual Review of Environment Resources, 28: 205-241.

LATORRE ML, CARVALHO JÚNIOR OA, SANTOS JR \& SHIMABUKURO YE. 2007. Integração de dados de sensoriamento remoto multi-resoluções para a representação da cobertura da terra utilizando campos contínuos de vegetação e classificação por árvores de decisão. Revista Brasileira de Geofísica, 25(1): 63-74.

MENKE AB, CARVALHO JÚNIOR OA, GOMES RAT, MARTINS ES \& OLIVEIRA SN. 2009. Análise das mudanças do uso agrícola da terra a partir de dados de sensoriamento remoto multitemporal no município de Luis Eduardo Magalhães (BA - Brasil). Sociedade e Natureza, 21: 315326.

PRINCE SD. 1991a. A model of regional primary production for use with coarse-resolution satellite data. International Journal of Remote Sensing, 12: $1313-1330$.

PRINCE SD. 1991b. Satellite remote sensing of primary production: Comparison of results for Sahelian grasslands 1981-1988. International Journal of Remote Sensing, 12: 1301-1313.

RAMANKUTTY N \& FOLEY J. 1998. Characterizing patterns of global land use: an analysis of global cropland data. Global Biogeochemistry Cycles, 12: 667-685.

RUNNING SW, LOVELAND TR, PIERCE LL, NEMANI RR \& HUNT ERJ. 1995. A remote sensing based vegetation classification logic for global land cover analysis. Remote Sensing of Environment, 51: 39-48.

SAKAMOTOT, YOKOZAWAM, TORITANI H, SHIBAYAMAM, ISHITSUKA N \& OHNO HA. 2005. Crop detection method using time-series MODIS data. Remote Sensing of Environment, 96: 366-374.

SANTANA OA, CARVALHO JÚNIOR OA, PIMENTEL CMM, GOMES RAT \& OLIVEIRA SN. 2010. Modelagem de espectros temporais NDVIMODIS, no período de 2000 a 2008, na Bacia do Rio Paracatu, Brasil. Revista Brasileira de Geofísica, 28(1): 47-60.

SILVA CR. 2008. Geodiversidade do Brasil: conhecer o passado, para entender o presente e prever o futuro. Rio de Janeiro, CPRM, 264 pp.
SMITH MO, JOHNSON PE \& ADAMS JB. 1985. Quantitative determination of mineral types and abundances from reflectance spectra using principal components analysis. Proc. $15^{\text {th }}$ Lunar Planet. Sci. Conf. Part 2. J. Geophys. Res., 90, Suppl., p. C797-C804.

SMITH MO, USTIN SL, ADAMS, JB \& GILLESPIE AR. 1990. Vegetation in deserts: I. a regional measure of abundance from multispectral images: Remote Sensing of the Environment, 31: 1-26.

TOMPKINS S, MUSTARD JF, PIETERS CM \& FORSYTH DW. 1997. Optimization of endmembers for spectral mixture analysis. Remote Sensing of Environment, 59: 472-489.

TRIMBLE S \& CROSSON P. 2000. US soil erosion rates: myth and reality. Science, 289: 248-250.

TUCKER CJ, NEWCOMB WW, LOS SO \& PRICE SD. 1991. Mean an interyear variation of growing season normalized difference vegetation index for the Sahel 1981-1989. International Journal of Remote Sensing, 12: 1133-1135.

VERMOTE E, EL SALEOUS N \& JUSTICE C. 2002. Atmospheric correction of the MODIS data in the visible to middle infrared: First results. Remote Sensing of Environment, 83(1-2): 97-111.

VITOUSEK PM, MOONEY HA, LUBCHENCO J \& MELILLO JM. 1997. Human domination of Earth's ecosystems. Science, 277: 494-499.

WESSELS KJ, PRINCE SD, FROST PE \& VAN ZYL D. 2004. Assessing the effects of human-induced land degradation in the former homelands of northern South Africa with a $1 \mathrm{~km}$ AVHRR NDVI time-series. Remote Sensing of Environment, 91: 47-67.

WINTER M. 1999. Fast autonomous spectral endmember determination in hyperspectral data. In: Int. Conf. Applied Geologic Remote Sensing, 13, Vancouver, BC, Canada, v. 2, p. 337-344.

WOLFE RE, ROY DP \& VERMOTE E. 1998. MODIS land data storage gridding and compositing methodology: level 2 grid. IEEE Transactions on Geoscience and Remote Sensing, 36: 1324-1338.

ZHANG X, FRIEDL MA, STRAHLER AH, HODGES JCF, GAO F, REED BC \& HUETE A. 2003. Monitoring vegetation phenology using MODIS. Remote Sensing of Environment, 84: 471-475.

Recebido em 2 abril, 2012 / Aceito em 28 junho, 2012

Received on April 2, 2012 / Accepted on June 28, 2012 


\section{NOTES ABOUT THE AUTHORS}

Antonio Felipe Couto Junior. Undergraduate degree in Forestry Engineering by Universidade de Brasília in 2003 and master degree in Forestry Science by the same institution in 2007. Is studying to obtain a doctor degree in Applied Geoscience at Instituto de Geociências of Universidade de Brasília. Presently is a professor at Universidade de Brasília, campus Planaltina. Carries out researches on temporal series analyses, cover changes, relations among relief, soil and vegetation.

Osmar Abílio de Carvalho Júnior. Undergraduate degree in Geology by Universidade de Brasília in 1990. Master and doctor degree in Mineral Prospecting by Universidade de Brasília in 1995 and 2000, respectively. Worked as a researcher of Instituto Nacional de Pesquisas Espaciais (INPE) between 2002 and 2004 . Presently is a professor at Universidade de Brasília and got a research productivity scholarship from CNPq. Carries out researches on digital processing of multispectral and hyperspectral images.

Éder de Souza Martins. Undergraduate degree in Geology by Universidade de Brasília, UNB, in 1987. Master (1987) and doctor (1999) degree in Geology by the same university. Presently works at Empresa Brasileira de Pesquisa Agropecuária, Centro de Pesquisa Agropecuária dos Cerrados, CPAC, coordinating the pedology laboratory. Carries out researches on methodologies for the cartographic mapping and generalization of pedologic information.

Vinícius Vasconcelos. Undergraduate degree in Geography by Universidade de Brasilia (2006). Master degree by the post-graduate program in the Geoprocessing for Territorial and Environmental Management area of the Departamento de Geografia. Experience in Geoscience area with emphasis in geomorphology, pedology and geoprocessing applied to pedogeomorphologic mapping. 